\title{
Book Shelf
}

๑) Society for International Development 2020

This section includes a selection of books, reports and other resources that may directly or indirectly relate to this Journal volume. The list is obviously not exhaustive. As an English language publication, this list only includes books and other resources available in English.

\section{Wuhan Diary: Dispatches from a Quarantined City Fang Fang and Michael Berry \\ HarperCollins Publisher, 2020 \\ ISBN: 9780063052659}

https://www.harpercollins.com/products/wuhan-diary-fangfangmichael-berry? variant $=32291831185442$

On 25 January 2020, after the central government imposed a lockdown in Wuhan, acclaimed Chinese writer Fang Fang began publishing an online diary. In the days and weeks that followed, Fang Fang's nightly postings gave voice to the fears, frustrations, anger, and hope of millions of her fellow citizens, reflecting on the psychological impact of forced isolation, the role of the internet as both community lifeline and source of misinformation, and most tragically, the lives of neighbors and friends taken by the deadly virus.

A fascinating eyewitness account of events as they unfold, Wuhan Diary captures the challenges of daily life and the changing moods and emotions of being quarantined without reliable information. Fang Fang finds solace in small domestic comforts and is inspired by the courage of friends, health professionals and volunteers, as well as the resilience and perseverance of Wuhan's nine million residents. But, by claiming the writer's duty to record she also speaks out against social injustice, abuse of power, and other problems which impeded the response to the epidemic and gets herself embroiled in online controversies because of it. As Fang Fang documents the beginning of the global health crisis in real time, we are able to identify patterns and mistakes that many of the countries dealing with the novel coronavirus have later repeated. She reminds us that, in the face of the new virus, the plight of the citizens of Wuhan is also that of citizens everywhere. As Fang Fang writes: 'The virus is the common enemy of humankind; that is a lesson for all humanity. The only way we can conquer this virus and free ourselves from its grip is for all members of humankind to work together'. Blending the intimate and the epic, the profound and the quotidian, Wuhan Diary is a remarkable record of an extraordinary time.

\section{Big Farms Make Big Flu: Dispatches on Infectious Disease, Agribusiness, and the Nature of Science}

Rob Wallace

MONTHLY REVIEW PRESS, 2016

ISBN-13: 978-1583675892

https://monthlyreview.org/product/big_farms_make_big_flu/

Thanks to breakthroughs in production and food science, agribusiness has been able to devise new ways to grow more food and get it more places more quickly. There is no shortage of news items on the hundreds of thousands of hybrid poultry-each animal genetically identical to the next-packed together in megabarns, grown out in a matter of months, then slaughtered, processed, and shipped to the other side of the globe. Less well known are the deadly pathogens mutating in, and emerging out of, these specialized agro-environments. In fact, many of the most dangerous new diseases in humans can be traced back to such food systems, among them Campylobacter, Nipah virus, $\mathrm{Q}$ fever, hepatitis $\mathrm{E}$, and a variety of novel influenza variants.

In Big Farms Make Big Flu, a collection of dispatches by turns harrowing and thought-provoking, Rob Wallace tracks the ways influenza and other pathogens emerge from an agriculture controlled by multinational corporations. With a precise and radical wit, Wallace juxtaposes ghastly phenomena such as attempts at producing featherless chickens with microbial time travel and neoliberal Ebola. Wallace also offers sensible alternatives to lethal agribusiness. Some, such as farming cooperatives, integrated pathogen management, and mixed crop-livestock systems, are already in practice off the agribusiness grid. 
Can't Pay, Won't Pay: The Case for Economic Disobedience and Debt Abolition

Debt Collective

Haymarket Books, 2020

ISBN: 9781642592627

https ://www.haymarketbooks.org/books/1520-cant-pay-won-t-pay

Debtors have been mocked, scolded and lied to for decades. We have been told that it is perfectly normal to go into debt to get medical care, to go to school, or even to pay for our own incarceration. We have been told there is no way to change an economy that pushes the majority of people into debt while a small minority hoard wealth and power. The coronavirus pandemic has revealed that mass indebtedness and extreme inequality are a political choice. In the early days of the crisis, elected officials drew up plans to spend trillions of dollars. The only question was: where would the money go and who would benefit from the bailout?

The truth is that there has never been a lack of money for things like housing, education and health care. Millions of people never needed to be forced into debt for those things in the first place. Time has come to defuse the explosive debts and to undermine the legitimacy of the punitive, profitable debt system of the current United States. Doing that is insurrectionary work, and uniting debtors in common cause is solidarity and justice work.

Armed with this knowledge, a militant debtors movement has the potential to rewrite the contract and assure that no one has to mortgage their future to survive. This is a the powerful tool they need: A Guide to Action for People in Debt.

\section{The Corona Crash: How the Pandemic Will Change Capitalism}

Grace Blakeley

Verso, 2020

ISBN: 9781839762055

https://www.versobooks.com/books/3723-the-corona-crash

In The Corona Crash, leading economics commentator Grace Blakeley theorizes about the epoch-making changes that the coronavirus brings in its wake. We are living through a unique moment in history. The pandemic has caused the deepest global recession since the Second World War. Meanwhile the human cost is reflected in a still-rising death toll, as many states find themselves unable-and some unwilling - to grapple with the effects of the virus. Whatever happens, we can never go back to business as usual.

This crisis will tip us into a new era of monopoly capitalism, argues Blakeley, as the corporate economy collapses into the arms of the state, and the tech giants grow to unprecedented proportions.

We need a radical response. The recovery could see the transformation of our political, economic, and social systems based on the principles of the Green New Deal. If not, the alternatives, as Blakeley warns, may be even worse than we feared.

\section{Care Manifesto: The Politics of Interdependence}

The Care Collective

Verso, 2020

ISBN: 9781839760969

https://www.versobooks.com/books/3706-care-manifesto

We are in the midst of a global crisis of care. How do we get out of it? The Care Manifesto puts care at the heart of the debates of our current crisis: from intimate care-childcare, healthcare, elder care-to care for the natural world. We live in a world where carelessness reigns, but it does not have to be this way.

The Care Manifesto puts forth a vision for a truly caring world. The authors want to reimagine the role of care in our everyday lives, making it the organizing principle in every dimension and at every scale of life. We are all dependent on each other, and only by nurturing these interdependencies can we cultivate a world in which each and every one of us can not only live but thrive.

The Care Manifesto demands that we must put care at the heart of the state and the economy. A caring government must promote collective joy, not the satisfaction of individual desire. This means the transformation of how we organize work through co-operatives, localism and nationalization. It proposes the expansion of our understanding of kinship for a more 'promiscuous care'. It calls for caring places through the reclamation of public space, to make a more convivial city. It sets out an agenda for the environment, most urgent of all, putting care at the centre of our relationship to the natural world.

Capitalism on Edge: How Fighting Precarity Can Achieve Radical Change Without Crisis or Utopia

Albena Azmanova

Columbia University Press, 2020

ISBN: 9780231195379

http://cup.columbia.edu/book/capitalism-on-edge/97802 31195379

The wake of the financial crisis has inspired hopes for dramatic change and stirred visions of capitalism's terminal collapse. Yet capitalism is not on its deathbed, utopia is not 
in our future, and revolution is not in the cards. In Capitalism on Edge, Albena Azmanova demonstrates that radical progressive change is still attainable, but it must come from an unexpected direction.

Azmanova's new critique of capitalism focuses on the competitive pursuit of profit rather than on forms of ownership and patterns of wealth distribution. She contends that neoliberal capitalism has mutated into a new form-precarity capitalism - marked by the emergence of a precarious multitude. Widespread economic insecurity ails the 99 percent across differences in income, education, and professional occupation; it is the underlying cause of such diverse hardships as work-related stress and chronic unemployment. In response, Azmanova calls for forging a broad alliance of strange bedfellows whose discontent would challenge not only capitalism's unfair outcomes but also the drive for profit at its core. To achieve this synthesis, progressive forces need to go beyond the old ideological certitudes of, on the left, fighting inequality and, on the right, increasing competition. Azmanova details reforms that would enable a dramatic transformation of the current system without a revolutionary break. An iconoclastic critique of left orthodoxy, Capitalism on Edgeconfronts the intellectual and political impasses of our time to discern a new path of emancipation.

\section{The COVID-19 Catastrophe: What's gone wrong and How to Stop it Happening Again}

Richard Horton

Wiley, 2020

ISBN: 978-1-509-54646-6

https ://www.wiley.com/en-it/The+COVID + 19+ Catastrophe $\% 3 \mathrm{~A}+$ What $\% 27 \mathrm{~s}+$ Gone + Wrong + and + How + to+Stop+It+Happening+Again-p-9781509546466

The global response to the COVID-19 pandemic is the greatest science policy failure in a generation. We knew this was coming. Warnings about the threat of a new pandemic have been made repeatedly since the 1980s and it was clear in January that a dangerous new virus was causing a devastating human tragedy in China. And yet the world ignored the warnings. Why?

In this short and hard-hitting book, Richard Horton, editor of the medical journal The Lancet, scrutinizes the actions that governments around the world took 'and failed to take' as the virus spread from its origins in Wuhan to the global pandemic that it is today. He shows that many Western governments and their scientific advisors made assumptions about the virus and its lethality that turned out to be mistaken. Valuable time was lost while the virus spread unchecked, leaving health systems unprepared for the avalanche of infections that followed. Drawing on his own scientific and medical expertise, Horton outlines the measures that need to be put in place, at both national and international levels, to prevent this kind of catastrophe from happening again.

We're supposed to be living in an era where human beings have become the dominant influence on the environment, but COVID-19 has revealed the fragility of our societies and the speed with which our systems can come crashing down. We need to learn the lessons of this pandemic and we need to learn them fast because the next pandemic may arrive sooner than we think.

\section{Critique and Praxis}

Bernard E. Harcourt

Columbia University Press, 2020

ISBN: 9780231195720

http://cup.columbia.edu/book/critique-and-praxis/97802 31195720

Critical philosophy has always challenged the division between theory and practice. At its best, it aims to turn contemplation into emancipation, seeking to transform society in pursuit of equality, autonomy, and human flourishing. Yet today's critical theory often seems to engage only in critique. These times of crisis demand more.

Bernard E. Harcourt challenges us to move beyond decades of philosophical detours and to harness critical thought to the need for action. In a time of increasing awareness of economic and social inequality, Harcourt calls on us to make society more equal and just. Only critical theory can guide us toward a more self-reflexive pursuit of justice. Charting a vision for political action and social transformation, Harcourt argues that instead of posing the question, 'What is to be done?' we must now turn it back onto ourselves and ask, and answer, 'What more am I to do?'

Critique and Praxis advocates for a new path forward that constantly challenges each and every one of us to ask what more we can do to realize a society based on equality and justice. Joining his decades of activism, social-justice litigation, and political engagement with his years of critical theory and philosophical work, Harcourt has written a magnum opus.

\section{Solved: How the World's Great Cities Are Fixing the Climate Strategy}

David Miller

University of Toronto Press, 2020

ISBN: 9781487506827

https://utorontopress.com/us/solved-3

Taking cues from progressive cities around the world, including Los Angeles, New York, Toronto, Oslo, 
Shenzhen, and Sydney, this book is a summons to every city to make small but significant changes that can drastically reduce our carbon footprint. We cannot wait for national governments to agree on how to reduce greenhouse gas emissions and manage the average temperature rise to within $1.5^{\circ}$. In Solved, David Miller argues that cities are taking action on climate change because they can-and because they must. Miller makes a clear-eyed and compelling case that, if replicated at pace and scale, the actions of leading global cities point the way to creating a more sustainable planet.

Solved: How the World's Great Cities Are Fixing the Climate Crisis demonstrates that the initiatives cities have taken to control the climate crisis can make a real difference in reducing global emissions if implemented worldwide. By chronicling the stories of how cities have taken action to meet and exceed emissions targets laid out in the Paris Agreement, Miller empowers readers to fix the climate crisis. As much a 'how to' guide for policymakers as a work for concerned citizens, Solved aims to inspire hope through its clear and factual analysis of what can be done-now, today - to mitigate our harmful emissions and pave the way to a $1.5^{\circ}$ world.

If our planet is going to survive the climate crisis, we need to act rapidly.

\section{Afrotopia}

Felwine Saar

Philippe Rey, 2016

ISBN: 978-2-84876-502-0

http://www.philippe-rey.fr/livre-Afrotopia-300-1-1-0-1.html

Africa has no one to catch up with. She should no longer run on the paths indicated to her, but walk quickly on the path she will have chosen. Her status as the eldest daughter of humanity requires her to extricate herself from competition, from this infantile age where nations look at each other to find out who has accumulated the most wealth, from this frantic and irresponsible race that puts in danger the social and natural conditions of life.

Its only urgency is to live up to its potential. She must complete her decolonization by a fruitful encounter with herself. In 35 years, its population will represent a quarter of that of the globe. It will constitute the living force. A demographic weight and a vitality which will tilt the social, political, economic and cultural balances of the planet. And to be this driving force, positive, it must accomplish a profound cultural revolution before giving birth to the novelty of which it is the bearer. It must participate in building a more conscious civilization, more concerned with the balance between the different orders, the common good, and dignity. This book is an act of faith in this active utopia: an Africa which helps to take humanity to another level.
Philanthropy: from Aristotle to Zuckerberg

Paul Vallely

Bloomsbury, 2020

ISBN: 9781472920126

https://www.bloomsbury.com/uk/philanthropy-9781472920 $126 /$

The super-rich are silently and secretly shaping our world. In this groundbreaking exploration of historical and contemporary philanthropy, bestselling author Paul Vallely reveals how this far-reaching change came about. Vivid with anecdote and scholarly insight, this magisterial survey-from the ancient Greeks to today's high-tech geeks-provides an original take on the history of philanthropy. It shows how giving has, variously, been a matter of honour, altruism, religious injunction, political control, moral activism, enlightened self-interest, public good, personal fulfilment and plutocratic manipulation.

Its narrative moves from the Greek man of honour and Roman patron, via the Jewish prophet and Christian scholastic-through the Elizabethan machiavel, Puritan proto-capitalist, Enlightenment activist and Victorian moralist- to the robber-baron philanthropist, the welfare socialist, the celebrity activist and today's wealthy mega-giver. In the process it discovers that philanthropy lost an essential element as it entered the modern era. The book then embarks on a journey to determine where today's philanthropists come closest to recovering that missing dimension.

Philanthropy explores the successes and failures of philanthrocapitalism, examines its claims and contradictions, and asks tough questions of top philanthropists and leading thinkers-among them Richard Branson, Eliza Manningham-Buller, Jonathan Ruffer, David Sainsbury, John Studzinski, Bob Geldof, Naser Haghamed, Lenny Henry, Jonathan Sacks, Rowan Williams, Ngaire Woods, and the presidents of the Rockefeller and Soros foundations, Rajiv Shah and Patrick Gaspard. In extended conversations they explore the relationship between philanthropy and family, faith, society, art, politics, and the creation and distribution of wealth. Highly engaging and meticulously researched, Paul Vallely's authoritative account of philanthropy then and now critiques the excessive utilitarianism of much modern philanthrocapitalism and points to how philanthropy can rediscover its soul.

\section{Artificial Whiteness: Politics and Ideology in Artificial Intelligence}

Yarden Katz

Colombia University Press, November 2020

ISBN: 9780231194914

http://cup.columbia.edu/book/artificial-whiteness/97802 31194914 
Dramatic statements about the promise and peril of artificial intelligence for humanity abound, as an industry of experts claims that $\mathrm{AI}$ is poised to reshape nearly every sphere of life. Who profits from the idea that the age of AI has arrived? Why do ideas of AI's transformative potential keep reappearing in social and political discourse, and how are they linked to broader political agendas?

Yarden Katz reveals the ideology embedded in the concept of artificial intelligence, contending that it both serves and mimics the logic of white supremacy. He demonstrates that understandings of AI, as a field and a technology, have shifted dramatically over time based on the needs of its funders and the professional class that formed around it. From its origins in the Cold War military-industrial complex through its present-day Silicon Valley proselytizers and eager policy analysts, AI has never been simply a technical project enabled by larger data and better computing. Drawing on intimate familiarity with the field and its practices,
Katz instead asks us to see how AI reinforces models of knowledge that assume white male superiority and an imperialist worldview. Only by seeing the connection between artificial intelligence and whiteness can we prioritize alternatives to the conception of $\mathrm{AI}$ as an all-encompassing technological force.

Bringing together theories of whiteness and race in the humanities and social sciences with a deep understanding of the history and practice of science and computing, Artificial Whiteness is an incisive, urgent critique of the uses of AI as a political tool to uphold social hierarchies.

Publisher's Note Springer Nature remains neutral with regard to jurisdictional claims in published maps and institutional affiliations. 